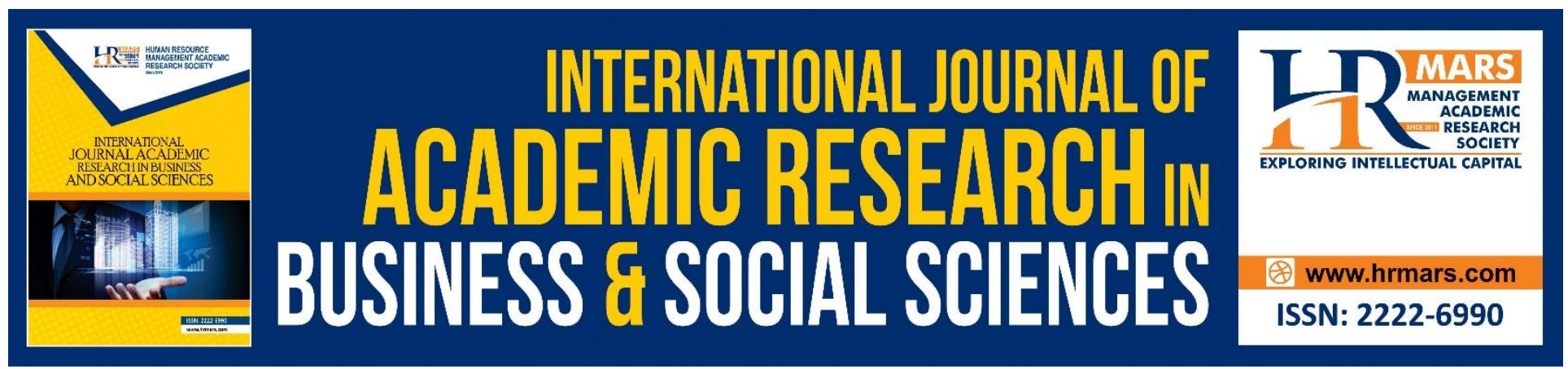

\title{
The Concept of Islamic Banking from the Islamic Worldview
}

\author{
Saidatolakma Mohd Yunus, Zuraidah Kamaruddin and Rahimah Embong
}

To Link this Article: http://dx.doi.org/10.6007/IJARBSS/v8-i11/4928

DOI: $10.6007 /$ IJARBSS/v8-i11/4928

Received: 09 Oct 2018, Revised: 27 Oct 2018, Accepted: 16 Nov 2018

Published Online: 29 Nov 2018

In-Text Citation: (Yunus, Kamaruddin, \& Embong, 2018)

To Cite this Article: Yunus, S. M., Kamaruddin, Z., \& Embong, R. (2018). The Concept of Islamic Banking from the Islamic Worldview. International Journal of Academic Research in Business and Social Sciences, 8(11), 539550.

Copyright: (C) 2018 The Author(s)

Published by Human Resource Management Academic Research Society (www.hrmars.com)

This article is published under the Creative Commons Attribution (CC BY 4.0) license. Anyone may reproduce, distribute, translate and create derivative works of this article (for both commercial and non-commercial purposes), subject to full attribution to the original publication and authors. The full terms of this license may be seen

at: http://creativecommons.org/licences/by/4.0/legalcode

Vol. 8, No. 11, 2018, Pg. 539 - 550

http://hrmars.com/index.php/pages/detail/IJARBSS

JOURNAL HOMEPAGE

Full Terms \& Conditions of access and use can be found at http://hrmars.com/index.php/pages/detail/publication-ethics 


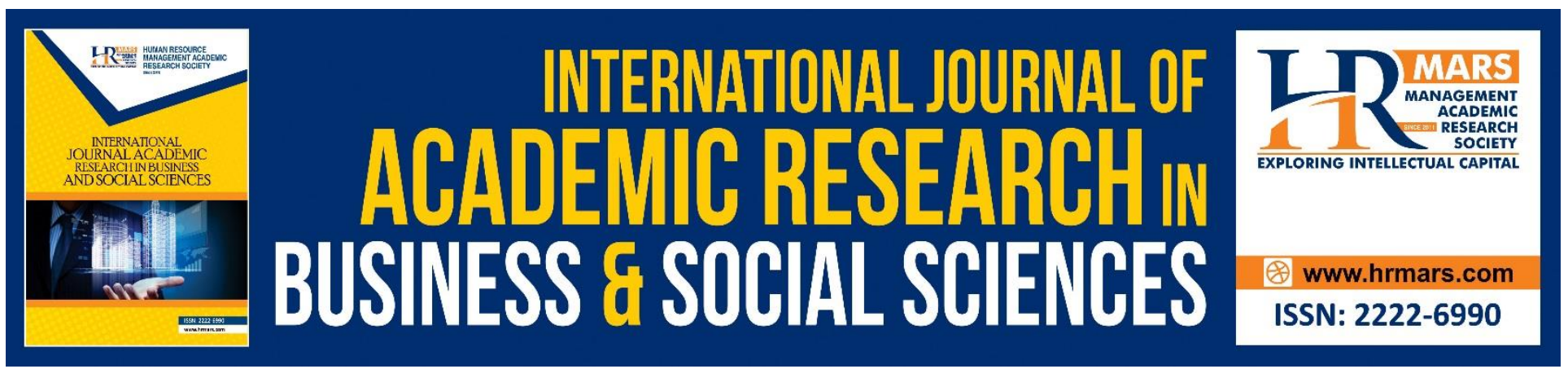

\title{
The Concept of Islamic Banking from the Islamic Worldview
}

\author{
${ }^{1}$ Saidatolakma Mohd Yunus, 'Zuraidah Kamaruddin and ${ }^{2}$ Rahimah \\ Embong \\ ${ }^{1}$ Kulliyyah of Islamic Revealed Knowledge and Human Sciences, \\ International Islamic University Malaysia \\ ${ }^{2}$ Faculty of General Studies \& Advanced Educations, Universiti Sultan Zainal Abidin, Malaysia
}

\begin{abstract}
Islamic banks are required to run their business activity with full conformity to Shariah. They should not borrow money on interest nor keep their surplus cash in interest bearing account as well as should not involve in any prohibited business deals. Even if the business activities are permissible, the borrowings may be based on riba (usury), the surplus is kept in interest bearing accounts and so on. Hence, this article aims to offer an alternative to liberate Muslim investors and small managers from the sinful action of dealing with those banking business activities.
\end{abstract}

Keywords: Islamic banking, Shari'ah compliance, Islamic banking activities

\section{Introduction}

The worldview, goals and strategy of economic system in Islam are derived from the Shari'ah. During the golden age of Islamic civilization, it was proved that Muslims were competent to establish Islamic financial system for mobilizing resources to finance productive activities and consumer needs without practicing riba' or interest (Chapra, 1992). It was also shown that the system run successfully for centuries (Iqbal \& Llewellyn, 2002).

Ibn al-Qayyim (2003) said: "The basis of the Shari'ah is wisdom and welfare of the people in this world as well as the Hereafter. This welfare lies in complete justice, mercy, well-being and wisdom. Anything that departs from justice to oppression, from mercy to harshness, from welfare to misery and from wisdom to folly, has nothing to do with the Shari'ah" (Chapra, 1992). Those who take usury will receive a painful torment for consuming the wealth of others without any right as Allah (SWT) has mentioned in the Holy Quran:

"Translation: And for their taking of usury while they had been forbidden from it, and their consuming of people's wealth unjustly. And We have prepared for the disbelievers among them a painful punishment" (An-Nisa', 4: 161) 


\section{Shariah Principles in Islamic Banking}

Before going into further discussion, Shariah principles underlying the Islamic banking operations and activities are discussed. The rational of having the discussion on the Shariah principles is due to the fact that the key principles are the determinants for the Islamic banks to stay compliant with the Shariah. Any Islamic bank that does not follow the Shariah principles may render Shariah noncompliant. The principles are like a benchmark to determine the operational status of Islamic banks. According to Ziauddin (2016) "Islamic banking" refers to the conduct of banking operations in consonance with Islamic teachings.

The principles of Islamic banking are derived from the Quran and the Sunnah. There are two sets of Shariah principles in Islam observed as far as Islamic banking is concerned. The first refers to the ideal objectives of Shariah that reflects the true picture of Islam and the second is based on some moderations that do not reflect the true picture of Islam. It is observed that the former is provided for usual circumstances while the latter is for unusual circumstances given in the time of extreme need (darurah).

In the context of Islamic banking system today, its operations, transactions and financial activities are much based on the second principle which does not follow the true picture of Islamic order due to its necessity to follow the unusual situation of today's business environment (Taqi, 2002). According to Taqi (2002), this situation is due to the fact that the Islamic banking system is too new when compared to the conventional banking system in which they face a lot of constraints to survive. It is evident when Islamic banks are established in the countries where the governments, central banks and legal as well as taxation system do not support the Islamic banking. These constraints put the Islamic banks in situation where they feel hard to be fully compliant with the Shariah requirements in some of their transactions. Therefore, certain acknowledgments /concessions/ relaxations have been given to Islamic banks on the basis of necessity (darurah) to facilitate their transactions.

This is not against the Shariah precepts as Islam has not detailed the rules in the Quran and Sunnah, in fact, left the matters for Muslim scholars to decide according to the suitability and appropriateness of the current time. Islam gives some relaxations for people in practicing Islam in all fields as for preserving the objectives of Shariah (maqasid Shariah) is very much important. However, the relaxations given by Islam in dealing within the complex economic world must adhere to the values and the principles of Islam.

The principles observed were meant for total development of the community. Thus according to Harran (1995) the banking activities must follow the philosophical principle that Allah (SWT) is the solely owner of the property and human being have to manage it in accordance with His Prescriptions. He further stated that the principle of Islamic banking in Islam is based on the profit and loss sharing in which one shares the profits and losses in business venture and not based on interest bearing loan to generate profit. It is further elucidated in the Quran (Surah Al-Baqarah Z: 275-278) of which Allah (SWT) has permitted trade as an alternative to riba for increasing wealth and generating profit. 
According to Manan \& Kamaluddin (2010 the Islamic banking and finance system is based on the concept of oneness of Allah (SWT) (tawhid), vicegerency (khalifah), trust (amanah) and brotherhood (ukhuwwah) derived from some Quranic verses such as Surah al-Baqarah: 29-30; Surah al-Anfaal: 27; and Surah al-Hujurat: 10. They concluded that the Islamic banking should therefore manage the resources in balance between individual and community rights as every individual has equal opportunity in the allocation and the distribution of resources endowed by Allah (SWT). Chapra (1992) in his book, Islam and the Economic Challenge, mentioned that the goal of Islamic banking is to attain justice and equitable distribution of wealth among the people.

In the view of Gerrard \& Cunningham (1997), it is important for Islamic banking to conform its activities to the Shariah principles while emphasizing on profits. It implies that under Islamic banking a profit must have a counter value that is in the form of risk. The involvement on profit and loss sharing and avoidance of element of riba are the important element must be applied in the operation of Islamic bank. These two main principles show that the profit procured through partnership is attached with risk of loss unlike the interest where no risk is incorporated to gain profits.

Besides, it is observed that Islam forbids element of riba, uncertainty (gharar) and gambling in which many literatures considered them major prohibition in Islamic banking (Harran, 1995; Thani, Mohamed Abdullah \& Hassan, 2003; Gerrard \& Cunningham, 1997; Khir et al., 2008). These major principles will be discussed in turn below.

\section{Riba}

According to Ibn Quddamah (2004) riba literally is an increase, growth and augmentation as elucidated in Quranic verses namely Surah Al-Imran: 130 and Surah Ar-Rom: 39. Technically it can be defined as growth in something or addition in the amount of principle (Quddamah, 2004). In a banking context, riba can be defined as an addition in the principle of loan in which the addition is based on the time value whereby no intervention made to cause the growth (Brian, 2011). It means that accumulation of wealth is done without effort. Khir et al. (2008) opined that riba applies to any benefit obtained from giving loan and extension of loan payment or now considered as interest.

Many classifications of riba have been made by the classical Muslim jurists and the contemporary Muslim scholars. According to Bakri (2011), a Muslim jurist of the Shafii school of thought categorized riba into three forms namely riba al-fadl (riba occurs through exchange surplus), riba al-nasi'ah (riba occurs through the deferment of time in payment) and riba yad (riba occurs through the postponement of usurious commodity in delivery). However Ibn Quddamah (2004) with reference to the hadith of the Prophet (解), the concept of riba refers to only riba fadhl and riba alnasiah.

This concept of riba is however in contradiction with the one observed in other studies (Rahman, 2010b; Khir et al., 2008). They classified riba into two forms. Firstly, riba duyun which is riba in debt contract and secondly riba buyu' which is riba in sales or exchange contract. Riba duyun 
occurs through financing transaction especially lending and borrowing while riba buyu' is related to trading transaction. For the former, Muslim scholars classified it into riba al-qard (riba occurs through excess conditioned to loan at a beginning of the contract) and riba jahiliyyah (riba occurs when excess imposed on the delay of debt payment) while the latter into riba al-fadl which occurs if the usurious items exchanged is not same in weight and quantity and riba al-nasiah or riba yad which occurs due to excess in deferred exchange.

It can be inferred that riba is classified on the basis of time value and quantity factors that produce excess in transaction without counter value. Each category of riba is strictly banned in Islam. The rationales behind the strict prohibition can be elucidated from many literatures (Ismail, 1989; Haron, 1997; Siddiqi, 2004; Khir et al., 2008; Nyazee, 2009; Rahman, 2010b; Bakri, 2011). From these literatures, it is found that many Muslim scholars have provided almost similar reasons behind the prohibition which can be summarized as the followings;

1. Prohibition of riba will lead to socio economic justice.

2. It will avoid declining moral and conduct and evade exploiting customer's hardship.

3. Help in nurturing competency and creating wealth justly.

4. The prohibition helps in preventing deprivation of Allah's (SWT) blessing on individual.

5. It will not deflect the function of money as a medium of exchange.

6. It will prevent exploitation on other people for a lender will gain profit unjustly when imposing compounding payment on borrower in the event of delay of time.

7. Islam emphasizes on hard work in accumulating wealth rather than interest which considered as selfish.

8. It avoids manipulative and tense relationship between people.

It can be inferred that, the rationale as to why Islam severely prohibits riba is mainly due to the basic teaching of Islam which is to develop harmony, equality and pleasure in all human beings. However, the real reason of the prohibition never reaches to the ultimate conclusion because of the limitation of human comprehension and restriction of human's rationale faculty. Prohibition of riba is merely a kind of ritual obedience (ta'bbud), simply applying riba is like declaring war to Allah (SWT) and His Messenger (Nyazee, 2009). There is a proof from the Quran where Allah (SWT) does not declare war except on those who deal in riba (. Allah (SWT) says:

"Translation: O you who believe! Observe your duty to Allah (SWT), and give up what remains from riba if you are true believers. And if you do not, then be warned of war from Allah (SWT) and His Messenger. But if you repent, you may have your principal thus you do no wrong, nor are you wronged"

(al-Baqarah: 278-279)

However, there is a claim that the practice of riba is unavoidable in this modern banking system in which without practicing it, the economy will not successfully function. It also creates confusion of to what extent the prohibition is applied whether the prohibition is meant to be imposed on the compounding riba only or including the simple riba (Nyazee, 2009). The statement of Federal 
Shariah Court of Pakistan as quoted by Brian (2011) shows that the concept of riba covers both usury and interest whether it is excessive or at minimum rate. With regards to the claim saying that the practice of riba is unavoidable in this current banking system, it is said that the claim is a wrong delusion and misinterpretation of the reason that all commands given by Allah (SWT) are within the capacity of human beings, thus riba is an avoidable practice (Ismail, 1989; Rahman, 2010a).

\section{Gharar (uncertainty)}

Gharar implies hazard, risk and uncertainty (Hassan, 2007) Many opinions have been provided by Muslim scholars in order to give good understanding on gharar. According to the Hanafi jurist alSarakhsi (1993) gharar implies something whose consequences are uncertain or concealed. The Maliki jurist Qarafi (1990) stated that gharar could occur in two situations which relates to the existence of the subject matter and its quantity or weight. The Shafie jurists, viewed gharar as a bargain whereby the subject matter is concealed in which its future result is unknown (Nawawi, 1925). The Hanbali jurist, Qayyim (2003) however viewed that gharar is uncertainty of subject matter to be delivered whether the subject matter is in existence or non-existence. From these views, it is elucidated that although the words are varied, the meaning of gharar they imposed is seemingly similar and acceptable.

According to Hassan (2007) gharar is a sale of good which is not in presence. Similarly it is understood that gharar entails unknown result and outcome to the contracting parties. This includes any transaction that is unclear in nature (Rahman, 2010a). Siddiqi (2006) attributed the unclear transaction is like those of practices occurred during the Prophet's time which have been regarded by the Prophet as gharar.

Hassan (2007) in his study highlighted some of the examples of sale in the Prophet's time which he viewed as to contain elements of gharar inter alia a sale of goods which are unknown and undetermined as regard to their quantity (bai' al-juzaf), a sale of non-available goods (bai' al$\left.m a^{\prime} d u m\right)$, a sale or purchase of gifts before they have been accepted, two sales in one sale, a "describe" sale (bai' muwasafah), a sale of good that is not possessed or a sale of good that is described without prior possession, sale of wool on the back of animal and sell of milk in udder, two conditions in a sale, a sale with a condition which give extra advantage to either party and sale with an exception. Mac Millan English Dictionary (2002) defines 'udder' as the part under the body of a cow and some other female animals, shaped like a small bag in which milk is produced.

In similar opinion, Khir et al. (2008) observed some of the transactions that contain gharar. According to him selling goods that the seller is unable to deliver, selling known or unknown goods against an unknown price, selling goods without proper description and selling goods without specifying the prices contain gharar. He added further that, making a contract conditional on an unknown event that happens at an unspecified time, selling goods on the basis of false description and selling goods without allowing the buyer to properly examine the goods are all involves element of gharar. 
The concept of gharar includes the inexistence of the subject matter, its unavailability to deliver, unknown quantities involved, unrevealed timing of completion, uncertain deliverability and unspecified price which can invalidate Islamic banking transaction. This can be further elucidated for instance in the case of selling birds in the sky and fish in the sea, selling goods with unknown prices and unknown quantity, selling undetermined goods (Rahman, 2010a).

Although gharar is prohibited in transactions, there are exceptions to make selling undeliverable goods become lawful. For example Quddamah (2004) opined that it is lawful selling fish while still in the water if the fish is owned (mamluk) and the water is shallow where the fish is possible to catch. In supporting this, a study by Rahman (2010a) viewed that this opinion is more relevant in today's situation with the development of modern technology that is capable to catch the fish in high accuracy. Siddiqi (2006) termed this kind of gharar as insurable gharar.

From these examples gharar have been classified into major (fahish) i.e (gharar is so significant and no means of quantifiying) and minor (yasir) gharar i.e (gharar is insignificant and able to ignore as does not lead to dispute) of the reasons today's life is full of situations where information is deficient and it sometimes impossible to avoid but tolerable in certain level (Siddiqi, 2006; Khir et al., 2008).

Further, Khir et al. (2008) categorized gharar into two namely major gharar/ excessive and minor/ slight gharar. He defined major gharar as an excessive gharar that can render a contract invalid. As for minor gharar, the example given was about selling fruits without peeling the skin and charging a fix amount for a bus fare for a fix distance although the whole distance is not travelled where the level of chance to dispute is very low. In line with this, a study shows that minor gharar is permitted based on the opinions of Muslim jurists from Maliki and Hanbali School of thoughts who said Islam provides some relaxation during facing complex situation especially those related to the economic transactions. Minor gharar also is believed to ease transactions and bring no bad implications to the contracting parties (Lahsasna, 2012). As for example, in the tabarrua't contracts (contracts of donation) like gift and donations the minor gharar is tolerable and acceptable in Shariah Currently there is another classification of gharar made by the Muslim scholars which is unavoidable gharar (la yumkin ihtiraz 'anhu) and moderate gharar (Lahsasna, 2012).

The rationales behind gharar prohibition are observed to avoid injustice, inequitability, hatred, devouring of other's wealth which eventually create disputes among the contracting parties. Siddiqi (2006) viewed the prohibition is to prevent unfairness and to make the maqasid Shariah (objectives of Shariah) realized. This is also to create satisfactory in both parties and ensure the income is lawful for consumption (Rahman, 2010a).

From the discussion it is observed that gharar in a transaction affects more on the subject matter which is the principal pillar of a contract. While it never takes effect in charitable transactions, it always comes into effect in the economic transaction like sale and purchase. In entering into a transaction, the contracting parties should ensure the condition of subject matter is free from non- 
INTERNATIONAL JOURNAL OF ACADEMIC RESEARCH IN BUSINESS AND SOCIAL SCIENCES

Vol. 8, No. 11, Nov, 2018, E-ISSN: 2222-6990 @ 2018 HRMARS

existence, unspecified price, no deliverability, unspecified characteristics and amounts to avoid gharar comes into effect as well as to avoid impermissible gain.

\section{Maysir (Gambling)}

Gambling refers to all forms of activities where procurement of money is depending entirely on chance or luck, no effort is incorporated in generating the money for instance through lottery or lucky draw (Vejzagic, 2012). In Quran (Surah Al-Maidah: 90), the prohibition of gambling is further laid down. Siddiqi (2006) in his study stressed that people fails to distinguish the difference between gambling in games of chance like betting in horse race, games of cards and spinning the roulette wheel and gambling in the ordinary business life. According to him, chances in business life involve risks and uncertainties (gharar) one has to take upon sale, purchase, investment and production. Financial risks involve in gambling can be illustrated in the derivatives like for example forward, futures and options transactions (Kunhibava \& Shanmugam, 2010). Similarly, Metwally (1997) said that other than prohibition of gambling in games and conventional banking activities, the prohibition also covers gambling in forward transactions.

Iqbal (2005) identifies gambling mostly occurs in insurance products where the concept is like buying and selling a guarantee for safeguarding customers from bad occurrence in the future. He further added that the excessive gharar contained in the subject matter will amount to gambling.

In line with this, Kunhibava \& Shanmugam (2010) enhanced the understanding on the relation between gharar and gambling. According to them, gambling is one of the subsets of gharar. Meaning that, gambling is one of the subgroups of gharar. He explained that uncertain result of gambling causes a transaction becomes gharar.

In relation to gambling, Qaradhawi (2003) stated that gambling brings in ill feeling like frustration, disappointment and angriness to either parties, loss of property without proper exchange, addiction which finally cause bankruptcy and non-productive person as his only desire is to get. For Buang (2000), the prohibition of gambling is not because of the nature but its resultant effect on those who are engaged in it. It creates hatred, enmity and hostility among the society and prevents Muslims from performing prayer and remembering Allah (SWT) as He mentions:

"Translation: They ask you about wine and gambling. Say, "In them is great sin and yet, some benefit for people. But their sin is greater than their benefit." And they ask you what they should spend. Say, "The excess beyond needs." Thus Allah makes clear to you the verses of revelation that you might give thought. They asked you about wine and gambling, say: "Therein is great sin and some benefit, and their sin is greater than their benefit" (Al-Baqarah, 2: 219)

In terms of economy, the prohibition of gambling helps in directing the savings towards real investment, preventing the basis for "liquidity preference" for gambling and restraining instability in short term investment (Metwally, 1997). 
It is observed from the discussion that gambling causes a person to win and lose merely through luck. This situation results in a person to use other people's money or property unjustly and unlawfully which is against the basic principle of justice, equity, fairness, ethics and morality as emphasized in Islam.

\section{Other Principles}

Besides the major prohibition of riba, gharar and gambling, there are other principles that must be observed by practitioners and supervisors for Shariah compliance. Islam forbids involvement in unlawful activities like trading of alcoholic drinks, dead animals, selling pork and manufacturing statues, stresses on sanctity and validity of contracts in transactions where sincerity and good intention of getting blessing from Allah (SWT) are inserted, emphasizes on morale principles in conducting business and promotes the concept of risk sharing in generating income (Quddamah, 2004; Qaradhawi, 2003; Khir et al., 2008; Bakar, 2008; Lahsasna, 2012; Gamal, 2000; Rahman; 2010a; Zuhayli, 2003; Baz, 1999).

The adherence to the Shariah principles will help strengthening the brotherhood and cooperation among the contracting parties, developing justice in economy and igniting strength in spiritual and moral values as well as preserving the objectives of Shariah. As mandated by Bank Negara Malaysia (BNM), all Islamic banks operated in Malaysia have to ensure their operations, transactions, activities and products in accordance with the prescribed Islamic principles as well as the statutory guidelines imposed by Bank Negara Malaysia (BNM) for compliance, otherwise purification is needed.

\section{Purification of Non-Halal Income (NHI)}

By not observing the Shariah principles, Islamic banking will fall into unlawful operations which will lead to the procurement of non-halal income (NHI). Purification of $\mathrm{NHI}$ or non-compliant income is an obligatory in Islam and it is a requirement for Islamic banks to dispose of any NHI realized as for being compliant with the Shariah. The purification of NHI has been discussed by traditional Muslim Jurists and contemporary Muslim scholars in their valuable works. As Islam is comprehensive, it delineates certain rules for purifying the non-Shariah property but it is not explained in minute details because it is left for Muslim scholars' ijtihad. Possessing as well as benefitting from non-Halal property is forbidden in Islam, thus, the property is required disposal. This is because Allah (SWT)

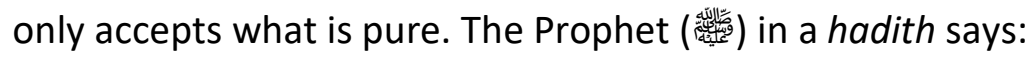

"Translation: No one gives charity equivalent to a date from that (earning) earned honestly, for Allah (SWT) accepts that which is lawful, the Lord would accept it with His Right Hand, and even if it is a date, it will foster in the Hand of the Lord, as one of you fosters his colt, till it becomes bigger than a mountain" (Muslim, 2001: 93)

In relation to this saying, Hafiz Ibn Hajar al-'Asqalani says that Allah (SWT) accepts only that charity which is given out of the wealth lawfully earned, for it is only that over which the man has legitimate and lawful claim. The wealth got through the unlawful means does not legitimately belong 
to the person who secures it by fould means. The charity from this wealth is not, therefore, acceptable to Allah (SWT) (Siddiqi, 1999)

Directing the non-halal property to the needy and charity for the benefit of Muslim ummah is grounded by the practice of the Prophet (p.b.u.h) which required Abu Bakr (RA) to hand over earnings obtained through betting on the decline of ancient Rome with Yahudi. People of Yahudi refuted its truth and once it eventually happened, they granted the companion an amount of money as earlier promised. When Abu Bakr (RA) presented it to the Prophet, he asked the companion to give it to charity for the benefit of Muslims for money obtained through betting is impure. This Hadith is recorded in (Al-Tirmidhi, 2002, Chapters on Tafsir). This is basically the basis of the purification of non halal income whereby it should be taken by Islamic banks in order to stay compliant.

\section{Conclusion}

The Shariah principles discussed in this paper are very crucial for Islamic banks to make sure Shariah compliance. However how far Islamic banks observe the principles in their operations, dealing, documentation and product advertisement become a question. As long as the NHI realized, the Islamic banks should take an immediate action to dispose and not to use it for the benefits of the banks for it is a sinful. Following the Islamic principles and undertaking the purification process are the requirements for Islamic banks to be fully Shariah compliant. To bear in mind that, Islamic banking purpose is not merely making profit but it is the way to uphold Islam by showing the uniqueness of Islamic finance which is totally different with the conventional system. Practically, the conventional system does not have certain principles with some concern to other people. In conventional banking system, profit is the main focus sought.

\section{Corresponding Author}

Saidatolakma Mohd Yunus, Department of Figh and Usul al-Fiqh, Kulliyyah of Islamic Revealed Knowledge and Human Sciences, International Islamic University Malaysia.

Email: akmayunus@iium.edu.my

\section{References}

Ahmad, Z. Islamic Banking: State of the Art, June 28, 2016, http://www.isdb.org/irj/go/km/docs/documents/IDBDevelopments/Internet/English/IRTI/C M/downloads/IES_Articles/Vol\%202-1..Ziauddin..ISLAMIC\%20BANKING.pdf

Al-Baz, A.A.M. (1999). Ahkam al-mal al-haram wa dawabitï al-intifa' wa al-ta'arruf bihi fi al-figh alIslami( $1^{\text {st }}$ edn.). Urdun: Dar al-Nafais.

Al-Harran, S. (1995). Time for Long-Term Islamic Financing. In Al-Harran, Saad (Ed.), Leading Issues in Islamic Banking and Finance (pp. 25-32). Petaling Jaya: Pelanduk Publication (M) Sdn. Bhd.

Al-Nawawi, A.Z.Y. (1925). al-Majmu' sharh al-muhadhdhab. Madinah al-Munawwarah: Maktabat alSalafiyyah.

AlNawawi, Abu Zakariya Yahya. (2001). Sahih Muslim bi sharh al-Nawawi. Matbu'ah al-Saqar.

Al-Qaradhawi, Y. (2003). The Lawful and the Prohibited in Islam (1 ${ }^{\text {st }}$ edn.). London: Al-Birr Foundation. 
INTERNATIONAL JOURNAL OF ACADEMIC RESEARCH IN BUSINESS AND SOCIAL SCIENCES

Vol. 8, No. 11, Nov, 2018, E-ISSN: 2222-6990 @ 2018 HRMARS

Al-Qarafi. (1990). Al-dhakhirah tahqiq Muhammad Haji. Bayrut: Dar al-Gharb al-Islami.

Al-Sarakhsi, A.B.M. (1993). Kitab al-mabsut. Bayrut: Dar al-Ma'rifah.

Al-Tirmidhi, Abu Isa Muhammad ibn Isa. (2002). Sunan al-Tirmidhi. Bayrut: Dar al-Ma'rifah.

Al-uhayli, W. . (2003). Al-fiqh al-Islami wa adillatuh. Bayrūt: Dar al-Fikr.

Bakar, M.D. (2008). Contracts in Islamic Commercial Law and Their Application in the Modern Islamic Financial System. In Mohd Daud Bakar \& Engku Rabiah Adawiah Engku Ali (Eds.), Essential Readings in Islamic Finance (pp. 47-85). Kuala Lumpur: CERT Publications Sdn. Bhd.

Bakri, Z.M. (2011). Kewangan Islam dalam Fiqh Shafie ( $1^{\text {st }}$ edn.). Kuala Lumpur: IBFIM.

Brian, K. (2011). Case Studies in Islamic Banking and Finance ( $1^{\text {st }}$ edn.). United Kingdom: Wiley.

Buang, A.H. (2000). Studies in the Islamic Law of Contracts: The Prohibition of Gharar. Kuala Lumpur: International Law Book Service.

Chapra, M.U. (1992). Islam and the Economic Challenge. Leicestershire, UK: The Islamic Foundation and International Institute of Islamic Thought (IIIT).

El-Gamal, M.A. (2000). A Basic Guide to Contemporary Islamic Banking and Finance. Houston: Rice University

Gerrard, P., \& Cunningham, J. B. (1997). Islamic Banking : A Study in Singapore International Journal of Bank Marketing, 15(6), 204-216. 5

Haron, S. (1997). Islamic Banking Rules and Regulations. Selangor: Pelanduk Publication (M) Sdn. Bhd. IbnQayyim, M.A.B. (2003). Zad al-ma'd hadyu khayr al-'Ibad. Bayrut: Dar al-Fikr

IbnQuddamah, M.A. (2004). al-Mughni. al-Qahirah: Dar al-Hadith.

Iqbal, M. \& Llewellyn, D.T. (2002). "Introduction," in Islamic Banking and Finance: New Perspectives on Profit Sharing and Risk, ed. Munawar Iqbal, David T. Llewellyn, UK: Edward Elgar Publishing Limited.

Iqbal, M. (2005). General Takaful Practice: Technical Approach to Eliminate Gharar (Uncertainty), Maysir (Gambling) and Riba (Usury). Jakarta: Gema Insani Press.

Ismail, H.M. (1989). Zakat Mal Haram. In Abs wa a'mal al-nadwah al-thaniyah li qadaya al-zakat almu'asirah (pp. 129-159). Kuwayt: Al-amanah alammah al-hai'ah al-Shar'iyyah al-'alamiyyah li al-zakat : Bayt al-zaka.

Khir, K. Gupta, L., \& Shanmugam, B. (2008). Islamic Banking: A Practical Perspective. Petaling Jaya: Pearson Malaysia Sdn. Bhd.

Kunhibava, S., \& Shanmugam, B. (2010). Shariah and Conventional Law Objections to Derivatives: A Comparison. Arab Law Quarterly, 24(4), 319-360.

Lahsasna, A. (2012). A Mini Guide to Islamic Contracts in Financial Services. Kuala Lumpur: Center for Research and Training (CERT).

Mac Millan English Dictionary. (2002). London: Mac Millan Publishers Limited.

Manan, S.K.A \& Kamaluddin, N. (2010). The Underlying Contracts of Isamic Banking (IB) Products and Some Related Issues in the Current Practice. Malaysian Accounting Review, Special Issue, 9(2), 99-144.

Metwally, M.M. (1997). Economic Consequences of Applying Islamic Principles in Muslim Societies. International Journal of Social Economics, 24(7/8/9), 941-957.

Nyazee, I.A.K. (2009). The Prohibition of Riba Elaborated. Lahore, Pakistan: The Federal Law House. 
INTERNATIONAL JOURNAL OF ACADEMIC RESEARCH IN BUSINESS AND SOCIAL SCIENCES

Vol. 8, No. 11, Nov, 2018, E-ISSN: 2222-6990 @ 2018 HRMARS

Rahman, Z.A. (2010a). Contracts \&The Products of Islamic Banking. Kuala Lumpur: CERT Publications Sdn Bhd.

Rahman, Z.A. (2010b). Riba dan Isu Kewangan Semasa. Kuala Lumpur: Telaga Biru.

Rosly, S.A. (2005). Islamic Banking : Doing Things Right and Doing Right Things. Malaysian Journal of Economic Studies, 42 (1 and 2), 31-40.

Siddiqi, A.H. (1999). Sahih Muslim (Arabic-Engish). Delhi: Adam Publishers and Distributors.

Siddiqi, M. N. (2004). Riba, Bank Interest and the Rationale of Its Prohibitions. Jeddah: Islamic Research and Training Institute.

Siddiqi, M. N. (2006). Islamic Banking and Finance in Theory and Practice: A Survey of State of the Art. Islamic Economic Studies, 13(2), 1-47.

Taqi, U.M. (2002). An Introduction to Islamic Finance. New York: Kluwer Law International.

Thani, N.N., Mohamed Abdullah, M.R. \& Hassan, M.H. (2003). Law and Practice of Islamic Banking and Finance. Petaling Jaya: Sweet \& Maxwell Asia.

Vejzagic, M. (2012). Future Contracts: Islamic Contract Law Perspectives. Paper presented at the 5th Islamic Banking, Accounting and Finance Conference 2012 (iBAF 2012). Faculty of Economics and Muamalat (FEM), Universiti Sains Islam Malaysia, 2-3 October 2012. Peer Reviewed Paper.

Ziauddin, A. (2016,June 28). Islamic Banking: State of the Art. http://www.isdb.org/irj/go/km/docs/documents/IDBDevelopments/Internet/English/IRTI/C M/downloads/IES_Articles/Vol\%202-1..Ziauddin..ISLAMIC\%20BANKING.pdf 